Article

\title{
Enzyme-Catalyzed Synthesis of Water-Soluble Conjugated Poly[2-(3-thienyl)-Ethoxy-4-Butylsulfonate]
}

\author{
Yun Zhao *, Hongyan Zhu, Xinyang Wang, Yingying Liu, Xiang Wu, Heyuan Zhou and \\ Zhonghai Ni *
}

School of Chemical Engineering and Technology, China University of Mining and Technology, Xuzhou 221116, China; zhuhongyan2014@126.com (H.Z.); 18796287559@163.com (X.W.); 18361226016@163.com (Y.L.); fangsiaixiedi@163.com (X.W.); zhouheyuanwork@163.com (H.Z.)

* Correspondence: zhaoyun@cumt.edu.cn (Y.Z.); nizhonghai@cumt.edu.cn (Z.N.); Tel.: +86-158-5203-5587 (Y.Z.); +86-158-5217-5309 (Z.N.)

Academic Editor: Katja Loos

Received: 17 March 2016; Accepted: 8 April 2016; Published: 13 April 2016

\begin{abstract}
An environmentally friendly water-soluble conjugated polythiophene poly[2-(3-thienyl)ethoxy-4-butylsulfonate] (PTEBS) has been found to be effective for making hybrid solar cells. In this work, we first report the enzyme-catalyzed polymerization of (3-thienyl)-ethoxy-4-butylsulfonate (TEBS) using horseradish peroxidase (HRP) enzyme as a catalyst and hydrogen peroxide $\left(\mathrm{H}_{2} \mathrm{O}_{2}\right)$ as an oxidant in an aqueous buffer. This enzyme-catalyzed polymerization is a "green synthesis process" for the synthesis of water-soluble conjugated PTEBS, the benefits of which include a simple setting, high yields, and an environmentally friendly route. Fourier transform infrared spectra (FTIR) and UV-Vis absorption spectra confirm the successful enzyme-catalyzed polymerization of TEBS. The thermo gravimetric (TG) data show the obtained PTEBS is stable over a fairly high range of temperatures. The present PTEBS has a good solubility in water and ethanol, and photoluminescence quenching of PTEBS/titanium dioxide $\left(\mathrm{TiO}_{2}\right)$ composite implies that the excitons dissociate and separate successfully at the interface of PTEBS and $\mathrm{TiO}_{2}$, which help to build solar cells using green processing methods.
\end{abstract}

Keywords: water-soluble polythiophene; enzyme-catalyzed polymerization; hybrid solar cell

\section{Introduction}

Conjugated polythiophenes have received significant attention recently due to their nonlinear optical properties, electro-conductivity, and other valuable properties. They can be employed in electrical components such as organic field-effect transistors (OFETs) and organic solar cells (OSCs) [1-5]. However, the processability and solubility of unsubstituted polythiophene is poor. The solubility in organic media can be markedly enhanced by introducing flexible alkyl chains, alkoxy groups, or other groups into the polymer backbone, which allow the wet solution preparation of thin film electrical devices via different coating and printing techniques $[6,7]$.

Alternatively, the hydrophilic side chains consist of charged groups, such as phosphonates, sulfonates, or carboxylates groups, that have been attached to polythiophenes to render the polymer water-soluble [8-10]. The function of using water as the solvent for the device fabrication process offers several advantages, such as environmentally friendly processing, which avoids toxic organic solvents, careful control of the evaporation of water using heat, which benefits the film morphology and improves stability of the devices under atmospheric conditions. Several works have already been reported OSCs fabricated from water-soluble poly[2-(3-thienyl)-ethoxy-4-butylsulfonate] (PTEBS) [11,12]. Traditionally, PTEBS has been synthesized by chemical oxidation methods $[13,14]$. 
Recently, enzymatic polymerization has been explored as an alternative approach to the synthesis of polymers [15-19]. The enzymes offer several advantages such as high selectivity, mild operating conditions, catalyst recyclability, and biocompatibility, which render them environmentally friendly alternatives over conventional chemical catalysts. These characteristics are indicative of the "green synthesis process" nature of the enzymatic catalysis for developing new polymeric materials. Several oxidoreductases (e.g., peroxidase, laccase, bilirubin oxidase, etc.) have been reported to catalyze the oxidative polymerization of $-\mathrm{OH}$ and $-\mathrm{NH}_{2}$ functionalized aromatic compounds [20-22]. Among them, horseradish peroxidase (HRP) is the most widely used biocatalyst for the polymerization of polyaromatic compounds such as phenols and anilines in the presence of hydrogen peroxide $\left(\mathrm{H}_{2} \mathrm{O}_{2}\right)$ as the oxidant.

In this work, we first report the enzyme-catalyzed synthesis of water-soluble conjugated polythiophene PTEBS using HRP as a catalyst and $\mathrm{H}_{2} \mathrm{O}_{2}$ as an oxidant. This enzyme-catalyzed polymerization is a "green synthesis process" for the synthesis of water-soluble conjugated PTEBS, the benefits of which include a simple setting, high yields, and an environmentally friendly route.

\section{Materials and Methods}

\subsection{General Considerations and Materials}

Horseradish peroxidase (HRP, EC1.11.1.7, $\geqslant 250$ units/mg, solid) were obtained from Sigma-Aldrich Co. (St. Louis., MO, USA) and were used without further purification. All the other chemicals were purchased from Sinopharm Chemical Reagent Co., Ltd. (Shanghai, China) and were of reagent grade. Dichloromethane was distilled from calcium hydride. The $4 \AA$ A molecular sieves were activated and stored in an oven at $200^{\circ} \mathrm{C}$ until use.

\subsection{Analytical Measurements}

${ }^{1} \mathrm{H}$ NMR spectra were collected on a Bruker-400 MHz spectrometer in $\mathrm{D}_{2} \mathrm{O}$ solutions with TMS as an internal standard (Bruker Corporation, Fällanden, Switzerland). The Fourier transform infrared (FTIR) measurements were recorded from KBr pellets by use of a Thermo Nicolet 750 FTIR spectrometer (Artisan Technology Group, Champaign, IL, USA). The weight-average molecular weight was estimated by P230 Gel Permeation Chromatography (GPC) (Elite, Dalian, China, column: SEC-150, XIYU Tech, Shanghai, China) with standard polystyrene as a reference using water as an eluent at $40^{\circ} \mathrm{C}$. UV-Vis absorption spectra were recorded on a Shimadzu UV-3600 UV-Vis-NIR spectrometer (Shimadzu Scientific Instruments, Kyoto, Japan). Emission spectra were performed by a Hitachi F-4600 fluorescence spectrometer (Hitachi High-Technologies Corporation, Tokyo, Japan). Thermo gravimetric (TG) analyses were performed on a TGA/SDTQ600 instrument (TA Instruments-A Division of Waters Ltd., Zellik, Belgium) at a heating rate of $20^{\circ} \mathrm{C} / \mathrm{min}$ under nitrogen.

\subsection{Synthesis of Monomer (3-thienyl)-Ethoxy-4-Butylsulfonate (TEBS)}

The monomer (3-thienyl)-ethoxy-4-butylsulfonate (TEBS) was synthesized by the method proposed in the literature [14]. To a mixed solution of 3-thienyl ethanol (5 mL; $27 \mathrm{mmol})$ and freshly distilled toluene $(200 \mathrm{~mL}), 1.31 \mathrm{~g}$ of sodium hydride $(55 \mathrm{mmol})$ was added slowly, which led to a white precipitate. The resultant mixture was stirred at room temperature for $30 \mathrm{~min}$, followed by $6.17 \mathrm{~g}$ of butanesultone ( $45 \mathrm{mmol}$ ) was added drop-wise, and the mixture was then refluxed for $2 \mathrm{~h}$ under the protection of nitrogen. The final pale yellow precipitate was obtained by filtration, washed with toluene, and dried under vacuum at $40{ }^{\circ} \mathrm{C}$ in $86 \%$ yield. The procedure is schematically depicted in Figure 1. UV-Vis: $\mathrm{H}_{2} \mathrm{O}$, max: $230 \mathrm{~nm}$. IR: KBr, $\left(\mathrm{cm}^{-1}\right)$ : 3079 (w, =C-H), 2927 (as, C-H), 2865 (s, C-H), 1453 (sh, $\left.\mathrm{CH}_{2}\right), 1206$ (s, S=O), 1065(s, C-O-C). ${ }^{1} \mathrm{H}$ NMR ( $\left.\mathrm{D}_{2} \mathrm{O}\right)$ (TMS, ppm): $7.44(\mathrm{~m}, 1 \mathrm{H}), 7.20(\mathrm{~m}, 1 \mathrm{H})$, $7.11(\mathrm{~m}, 1 \mathrm{H}), 3.78(\mathrm{t}, 2 \mathrm{H}), 3.57(\mathrm{t}, 2 \mathrm{H}), 2.94(\mathrm{t}, 2 \mathrm{H}), 2.91(\mathrm{t}, 2 \mathrm{H}), 1.69-1.76(\mathrm{~m}, 4 \mathrm{H})$ (Figure S1). 

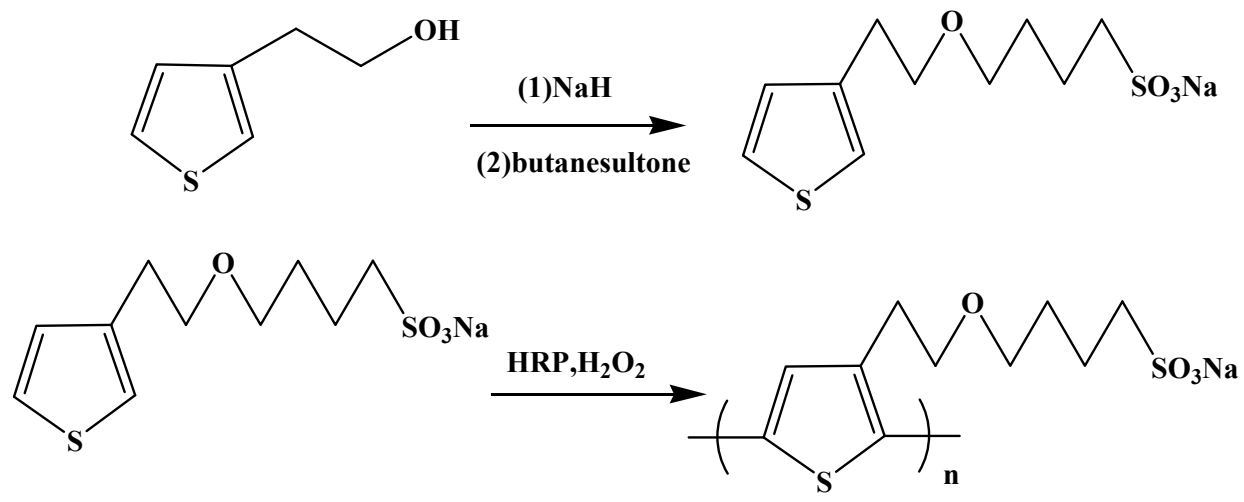

Figure 1. Scheme of enzyme-catalyzed polymerization of water-soluble (3-thienyl)-ethoxy-4butylsulfonate (TEBS) with horseradish peroxidase (HRP).

\subsection{Enzyme-Catalyzed Polymerization of TEBS}

The polymerization of TEBS was catalyzed by HRP with a hydrogen peroxide $\left(\mathrm{H}_{2} \mathrm{O}_{2}\right)$ oxidant, which is schematically depicted in Figure 1. Firstly, $2.8 \mathrm{~g}$ of monomer TEBS (11 mmol) was dissolved in $4 \mathrm{~mL}$ of distilled water at room temperature. Next, the $\mathrm{pH}$ was adjusted to 3.0 with the addition of hydrochloric acid, and the temperature was adjusted to $5{ }^{\circ} \mathrm{C}$. A stock solution of $\mathrm{HRP}(3 \mathrm{mg} / \mathrm{mL})$ was also prepared in distilled water, and $0.15 \mathrm{~mL}$ of a HRP solution were added to the typical reaction mixture under magnetic stirring. The polymerization was initiated by the addition of an $\mathrm{H}_{2} \mathrm{O}_{2}$ solution accompanied with the change of color of the reaction solution from faint yellow to red. The $\mathrm{H}_{2} \mathrm{O}_{2}$ solution ( $1 \mathrm{mmol}, 30 \mathrm{wt} \%$ ) was added to the mixture every $10 \mathrm{~min} 11$ times to prevent inhibition of the enzyme activity. The reaction was carried out at $5^{\circ} \mathrm{C}$ for $16 \mathrm{~h}$, and the solution was then transferred to degradable natural cellulose membrane bags (molecular weight cut off $4000 \mathrm{Da}$ ) and was dialyzed against $1000 \mathrm{~mL}$ of distilled water. Dialysis was carried out for $48 \mathrm{~h}$ with distilled water, being changed every $6 \mathrm{~h}$ to expedite the removal of enzyme, oligomers, and unreacted monomer. The red brown polymer was achieved by removing the solvent by distillation in vacuum at $40{ }^{\circ} \mathrm{C}$ for $24 \mathrm{~h}$. UV-Vis: $\mathrm{H}_{2} \mathrm{O}$, max: 287 and $351 \mathrm{~nm}$. IR: $\mathrm{KBr},\left(\mathrm{cm}^{-1}\right)$ : 2925 (as, C-H), 2857 (s, C-H), 1460 (sh, $\mathrm{CH}_{2}$ ), 1206 (s, $\mathrm{S}=\mathrm{O}), 1065(\mathrm{~s}, \mathrm{C}-\mathrm{O}-\mathrm{C}) .{ }^{1} \mathrm{H}$ NMR $\left(\mathrm{D}_{2} \mathrm{O}\right)$ (TMS, ppm): $3.51(\mathrm{t}, 2 \mathrm{H}), 3.44(\mathrm{t}, 2 \mathrm{H}), 2.89(\mathrm{t}, 2 \mathrm{H}), 2.82(\mathrm{t}, 2 \mathrm{H})$, $1.54-1.70(\mathrm{~m}, 4 \mathrm{H})$ (Figure $\mathrm{S} 2)$.

\section{Results and Discussion}

\subsection{The Successful Enzyme-Catalyzed Polymerization of TEBS}

Following a synthetic procedure described in a recent publication [14], the monomer (3-thienyl)ethoxy-4-butylsulfonate (TEBS) was easily synthesized in one step with a good yield (86\%) from the commercially available 3-thienyl ethanol. Then the oxidative polymerization was carried out in water using horseradish peroxidase (HRP) enzyme as a catalyst, and hydrogen peroxide $\left(\mathrm{H}_{2} \mathrm{O}_{2}\right)$ as an oxidant. The gravimetric yield of polymerization was $53 \%$ (Table 1, entry 1 ). It was reported that acidic media is necessary for enzyme-catalyzed polymerization $[16,23]$. The protonic acids used here catalyzed the equilibrium reaction to the corresponding polymer and increased the yield of the polymerization. However, it is known that the activity of the HRP enzyme would decrease in acidic media. Thus, the temperature should be kept lower $\left(5^{\circ} \mathrm{C}\right)$ to decrease the degradation of the HRP enzyme. We had carried out the enzymatic polymerization at room temperature following the same procedure; however, the yield decreased to $40 \%$ (Table 1, entry 2).

Different reaction conditions were also studied to establish the optimum one for the enzyme-catalyzed synthesis of poly[2-(3-thienyl)-ethoxy-4-butylsulfonate] (PTEBS), as shown in Table 1. As we can see, the enzymatic polymerization, which was carried out following the same procedure but with five times the amount of HRP, the yield changed little (entry 1-3). However, 
it would have caused too much time to dialyze for the removal of enzyme. The reaction time was also adjusted from 16 to $24 \mathrm{~h}$ to increase the yield; however, the yield did not obviously increase (entry 1-4). As a result, we terminated the reaction at $16 \mathrm{~h}$ for convenience. The amount of $\mathrm{H}_{2} \mathrm{O}_{2}$ was also investigated. Experiments were run with three different molar ratios of TEBS and $\mathrm{H}_{2} \mathrm{O}_{2}$ (2:1, 1:1, 1:2; entry 5, 1, 6, respectively). An increased yield from $21 \%$ to $53 \%$ was observed, when the ratio of TEBS and $\mathrm{H}_{2} \mathrm{O}_{2}$ changed from 2:1 to 1:1. When the ratio of oxidant was two times the monomer, the yield started to decrease. We demonstrated that one molecule of the monomer TEBS requires one molecule of the oxidant $\mathrm{H}_{2} \mathrm{O}_{2}$ for polymerization. The higher concentration of $\mathrm{H}_{2} \mathrm{O}_{2}$ likely inhibited the HRP enzyme activity.

Table 1. Enzyme-catalyzed polymerization of TEBS at different reaction conditions ${ }^{1}$.

\begin{tabular}{cccccc}
\hline Entry & $\begin{array}{c}\text { Reaction } \\
\text { temperature }\left({ }^{\circ} \mathbf{C}\right)\end{array}$ & $\begin{array}{c}\text { Reaction time } \\
(\mathbf{h})\end{array}$ & $\begin{array}{c}\text { Amount of } \\
\text { HRP (mg) }\end{array}$ & $\begin{array}{c}\text { Molar ratio of } \\
\text { TEBS: } \mathbf{H}_{\mathbf{2}} \mathbf{O}_{\mathbf{2}}\end{array}$ & $\begin{array}{c}\text { Yield } \\
(\mathbf{\%})\end{array}$ \\
\hline 1 & 5 & 16 & 0.45 & $1: 1$ & 53 \\
2 & 25 & 16 & 0.45 & $1: 1$ & 40 \\
3 & 5 & 16 & 2.25 & $1: 1$ & 56 \\
4 & 5 & 24 & 0.45 & $1: 1$ & 54 \\
5 & 5 & 16 & 0.45 & $2: 1$ & 21 \\
6 & 5 & 16 & 0.45 & $1: 2$ & 38 \\
\hline
\end{tabular}

${ }^{1}$ The amount of monomer TEBS is $11 \mathrm{mmol}$.

However, the molecular weight of the obtained PTEBS is low. Gel permeation chromatography (GPC) measurements revealed a weight-average molecular weight of $1650 \mathrm{~g} / \mathrm{moL}$ with a polydispersity index of 1.2 (Figure S3). In recent years, we have shown that the synthesis of conducting polymers such as poly(3,4-ethylenedioxythiophene) (PEDOT) can be carried out enzymatically in a good yield [23]. However, TEBS is not as easily polymerized as 3,4-ethylenedioxythiophene (EDOT) without its electron-donating oxygen atoms, which can decrease the oxidation potential. Therefore, the molecular weight remains limited. The chemical natural of the polymer was studied by FTIR spectroscopy. Figure 2 shows the FTIR spectra of monomer TEBS and as-synthesized polymer PTEBS. A peak at $3079 \mathrm{~cm}^{-1}$ in the FTIR spectra of monomer TEBS is due to the $\mathrm{C}-\mathrm{H}$ bond stretching in the thiophene ring. The most significant feature, however, was the absence of a peak at $3079 \mathrm{~cm}^{-1}$ for the spectrum of PTEBS, proving the successful enzyme-catalyzed polymerization of PTEBS. Furthermore, the absorption peak at $883 \mathrm{~cm}^{-1}$ ascribable to the $\mathrm{C}-\mathrm{H} \alpha$ out-of-plane deformation of thiophene rings is found to be rather weak, which indicating that the thiophene rings were polymerized by $\alpha-\alpha^{\prime}$ coupling [24].

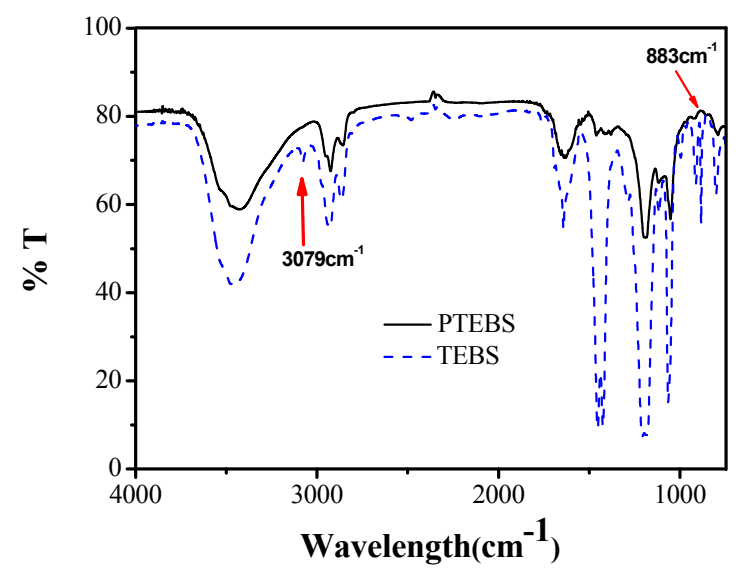

Figure 2. Fourier transform infrared (FTIR) spectra of monomer TEBS and polymer poly[2-(3-thienyl)ethoxy-4-butylsulfonate] (PTEBS). 
Moreover, conjugation was also confirmed by the UV-Vis spectrum of the polymer. The UV-Vis spectrums of monomer TEBS and as-synthesized polymer PTEBS are shown in Figure 3. As seen in the figure, the monomer TEBS did not show significant absorption above $300 \mathrm{~nm}$. However, the UV-Vis spectrums of the obtained PTEBS give a peak at $352 \mathrm{~nm}$ in the water solution corresponding to the $\pi-\pi^{*}$ transition. The spectra of the obtained PTEBS are red-shifted compared to the monomer, attributed to a distribution of conjugation lengths, which further confirms the success of enzyme-catalyzed polymerization. However, the absorption of the PTEBS was limited by finite confinement of the $\pi$-conjugated length, caused by limited long-range order, in agreement with the low molecular weight of the PTEBS previously obtained [25].

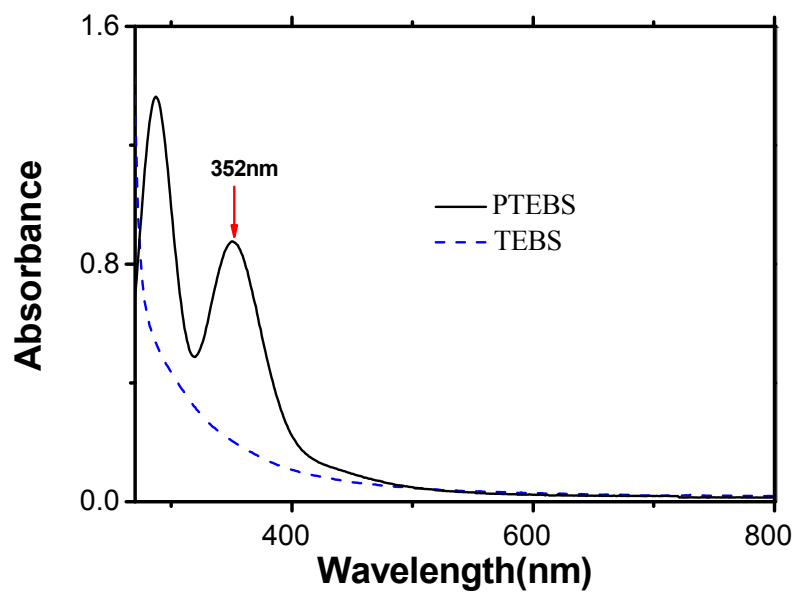

Figure 3. UV-Vis spectra of monomer TEBS and polymer PTEBS.

\subsection{Thermal Analysis}

The process of thermal annealing has been demonstrated to considerably increase the performance of the organic solar cells (OSCs) [26-29]. Therefore, thermal properties of the PTEBS obtained were evaluated by Thermo gravimetric (TG) analyses. The TG trace of the PTEBS solid is shown in the insert of Figure 4 . The measurements were performed under nitrogen. The initial decrease in weight percent is due to evaporation of bound water. The enzymatically synthesized PTEBS is fairly stable up to $300^{\circ} \mathrm{C}(75 \mathrm{wt} \%$ is remained) and then starts to decompose. These data show the high thermal stability of the present PTEBS, which is stable over a fairly high range of temperatures. The high thermal stability may be greatly helpful for its potential applications.

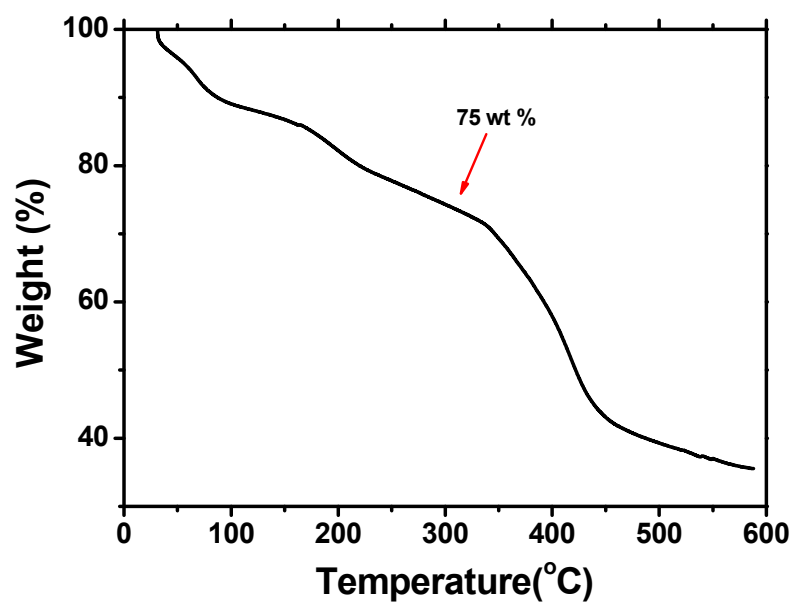

Figure 4. TG curve of polymer PTEBS heated from 0 to $600{ }^{\circ} \mathrm{C}$. 


\subsection{The Potential for Using in Solar Cells}

The obtained PTEBS has a good solubility in water and ethanol. The benefits of using water as the solvent are numerous, such as easily controlled evaporation rates, environmental friendliness, and improved stability under atmospheric conditions. Water-soluble polythiophene is also compatible with a number of different processing techniques, which help to build high efficiency solar cells using low cost materials and processing methods.

Inorganic nano-particles such as titanium dioxide $\left(\mathrm{TiO}_{2}\right)$ often serve as electron acceptors to build hybrid solar cells. Thus, the photovoltaic response of the PTEBS was tested by performing the photoluminescence (PL) intensity of the PTEBS/ $\mathrm{TiO}_{2}$ composite, which can indicate, and help us understand, the charge separation and transfer in the composites [12]. Figure 5 shows the PL of the pure PTEBS and the PTEBS/ $/ \mathrm{TiO}_{2}$ composite that contains PTEBS and $\mathrm{TiO}_{2}$ with a ratio of 1:1 by weight. As shown in Figure 5, there is a significant quenching of the fluorescence in the composite as compared to the pure PTEBS, which implies that the excitons dissociate and separate successfully at the interface of PTEBS (donor) and $\mathrm{TiO}_{2}$ (acceptor). It renders this obtained PTEBS a very promising candidate of donor material for organic solar cells.

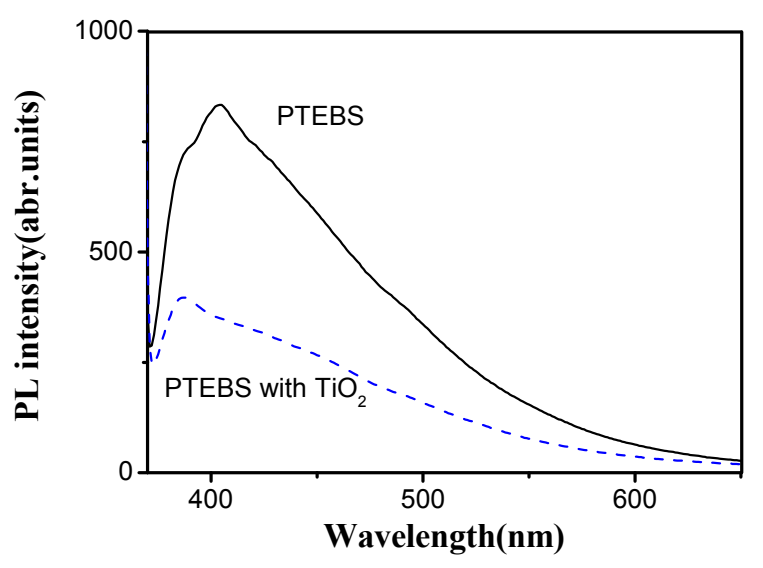

Figure 5. Photoluminescence of $\mathrm{PTEBS} / \mathrm{TiO}_{2}$ water solution.

Traditionally, PTEBS was synthesized by chemical oxidation methods. In this work, PTEBS was first synthesized using enzyme-catalyzed method. This enzyme-catalyzed polymerization is a "green synthesis process," the benefits of which include a simple setting, high yields, and an environmentally friendly route. The obtained PTEBS can build hybrid solar cells with inorganic nano-particles such as $\mathrm{TiO}_{2}$ using water as a solvent, which helps towards easily controlled evaporation rates and an environmentally friendly route. The performance of the solar cells can be increased by thermal annealing for the high thermal stability of PTEBS.

\section{Conclusions}

In summary, we have suggested a facile enzyme-catalyzed polymerization method to synthesize a water-soluble poly[2-(3-thienyl)-ethoxy-4-butylsulfonate] (PTEBS), using (3-thienyl)ethoxy-4-butylsulfonate (TEBS) as a monomer, a horseradish peroxidase (HRP) enzyme as a catalyst, and hydrogen peroxide $\left(\mathrm{H}_{2} \mathrm{O}_{2}\right)$ as an oxidant. This enzymatic polymerization is a new approach for the synthesis of PTEBS, the benefits of which include a simple setting, high yields, and an environmentally friendly route. These characteristics are indicative of the "green synthesis process" nature of the enzymatic catalysis for developing new polymeric materials. The present PTEBS has a good solubility in water and ethanol, and the excitons dissociate and separate successfully at the interface of PTEBS and $\mathrm{TiO}_{2}$, which help to build solar cells using green processing methods. 
Supplementary Materials: The following are available online at www.mdpi.com/2073-4360/8/4/139/s1: Figure S1: ${ }^{1} \mathrm{H}$ NMR spectrum of (3-thienyl)-ethoxy-4-butylsulfonate (TEBS); Figure S2: ${ }^{1} \mathrm{H}$ NMR spectrum of poly[2-(3-thienyl)-ethoxy-4-butylsulfonate] (PTEBS); Figure S3: GPC trace of PTEBS.

Acknowledgments: The Project was supported by the Fundamental Research Funds for the Central Universities (No. 2015QNA24).

Author Contributions: Yun Zhao and Zhonghai Ni conceived and designed the experiments; Hongyan Zhu and Xinyang Wang performed the experiments; Yingying Liu, Xiang Wu, and Heyuan Zhou analyzed the data; Yun Zhao wrote the paper.

Conflicts of Interest: The authors declare no conflict of interest.

\section{References}

1. Chen, S.A.; Ni, J.M. Structure/properties of conjugated conductive polymers. 1. Neutral poly(3-alkyl thiophene). Macromolecules 1992, 25, 6081-6089. [CrossRef]

2. Yamamoto, T.; Komarudin, D.; Arai, M.; Lee, B.L.; Suganuma, H.; Asakawa, N.; Inoue, Y.; Kubota, K.; Sasaki, S.; Fukuda, T.; et al. Extensive studies on $\pi$-stacking of poly(3-alkylthiophene-2,5-diyl)s and poly(4-alkylthiazole-2,5-diyl)s by optical spectroscopy, NMR analysis, light scattering analysis, and X-ray crystallography. J. Am. Chem. Soc. 1998, 120, 2047-2058. [CrossRef]

3. Kim, Y.; Cook, S.; Tuladhar, S.M.; Choulis, S.A.; Nelson, J.; Durrant, J.R.; Bradley, D.D.C.; Giles, M.; Mcculloch, I.; Ha, C.S.; et al. A strong regioregularity effect in self-organizing conjugated polymer films and high-efficiency polythiophene: Fullerene solar cells. Nat. Mater. 2006, 5, 197-203. [CrossRef]

4. Karahka, M.; Kreuzer, H.J. Conduction and electrostriction of polymers induced by high electric fields. Polymers 2011, 3, 51-64. [CrossRef]

5. Zhao, Y.; Wang, X.; Shu, F. Investigation of multi-donor bulk-heterojunction photovoltaic cells based on P3HT:PCBM system. Sol. Energ. Mat. Sol. Cells 2011, 95, 684-687. [CrossRef]

6. Chen, T.A.; Wu, X.; Rieke, R.D. Regiocontrolled synthesis of poly(3-alkylthiophenes) mediated by rieke zinc: Their characterization and solid-state properties. J. Am. Chem. Soc. 1995, 117, 233-244. [CrossRef]

7. Pal, S.; Nandi, A.K. Cocrystallization mechanism of poly(3-alkyl thiophenes) with different alkyl chain length. Polymer 2005, 46, 8321-8330. [CrossRef]

8. Chen, L.; Kim, B.; Nishino, M.; Gong, J.P.; Osada, Y. Environmental responses of polythiophene hydrogels. Macromolecules 2000, 33, 1232-1236. [CrossRef]

9. Mwaura, J.K.; Pinto, M.R.; Witker, D.; Ananthakrishnan, N.; Schanze, K.S.; Reynolds, J.R. Photovoltaic cells based on sequentially adsorbed multilayers of conjugated poly( $p$-phenylene ethynylene)s and a water-soluble fullerene derivative. Langmuir 2005, 21, 10119-10126. [CrossRef] [PubMed]

10. Wang, H.; Xia, B.; Yan, Y.; Li, N.; Wang, J.Y.; Wang, X. Water-soluble polymer exfoliated graphene: As catalyst support and sensor. J. Phys. Chem. B 2013, 117, 5606-5613. [CrossRef] [PubMed]

11. Qiao, Q.; McLeskey, J.T., Jr. Water-soluble polythiophene/nanocrystalline $\mathrm{TiO}_{2}$ solar cells. Appl. Phys. Lett. 2005, 86. [CrossRef]

12. McLeskey, J.T., Jr.; Qiao, Q. Hybrid solar cells from water-soluble polymers. Int. J. Photoenergy 2006, 2006, 1-6. [CrossRef]

13. Tran-Van, F.; Carrier, M.; Chevrot, C. Sulfonated polythiophene and poly(3,4-ethylenedioxythiophene) derivatives with cations exchange properties. Synth. Met. 2004, 142, 251-258. [CrossRef]

14. Cabarcos, E.L.; Carter, S.A. Effect of the molecular weight and the ionic strength on the photoluminescence quenching of water-soluble conjugated polymer sodium poly[2-(3-thienyl)ethyloxy-4-butylsulfonate]. Macromolecules 2005, 38, 10537-10541. [CrossRef]

15. Gross, R.A.; Kumar, A.; Kalra, B. Polymer synthesis by in vitro enzyme catalysis. Chem. Rev. 2001, 101, 2097-2124. [CrossRef] [PubMed]

16. Bruno, F.F.; Fossey, S.A.; Nagarajan, S.; Nagarajan, R.; Kumar, J.; Samuelson, L.A. Biomimetic synthesis of water-soluble conducting copolymers/homopolymers of pyrrole and 3,4-ethylenedioxythiophene. Biomacromolecules 2006, 7, 586-589. [CrossRef] [PubMed]

17. Kadokawa1, J.; Kobayashi, S. Polymer synthesis by enzymatic catalysis. Curr. Opin. Chem. Biol. 2010, 14, 145-153. [CrossRef] [PubMed] 
18. Kazariya, A.; Matsumura, S. Enzymatic synthesis and crosslinking of novel high molecular weight polyepoxyricinoleate. Polymers 2012, 4, 486-500. [CrossRef]

19. Mohan, T.; Rathner, R.; Reishofer, D.; Koller, M.; Elschner, T.; Spirk, S.; Heinze, T.; Stana-Kleinschek, K.; Kargl, R. Designing hydrophobically modified polysaccharide derivatives for highly efficient enzyme immobilization. Biomacromolecules 2015, 16, 2403-2411. [CrossRef] [PubMed]

20. Kobayashi, S.; Uyama, H.; Takamoto, T. Lipase-catalyzed degradation of polyesters in organic solvents. A new methodology of polymer recycling using enzyme as catalyst. Biomacromolecules 2000, 1, 3-5. [CrossRef] [PubMed]

21. Kobayashi, S.; Makino, A. Enzymatic polymer synthesis: An opportunity for green polymer chemistry. Chem. Rev. 2009, 109, 5288-5353. [CrossRef] [PubMed]

22. Sandy, M.; Carter-Franklin, J.N.; Martin, J.D.; Butler, A. Vanadium bromoperoxidase from Delisea pulchra: Enzyme-catalyzed formation of bromofuranone and attendant disruption of quorum sensing. Chem. Commun. 2011, 47, 12086-12088. [CrossRef] [PubMed]

23. Duan, L.; Zhao, Y.; Guo, F.; Liu, W.; Hou, C.; Ni, Z. Enzymatic-catalyzed polymerization of water-soluble electrically conductive polymer PEDOT:PSS. Polym. Adv. Technol. 2014, 25, 896-899. [CrossRef]

24. $\mathrm{Hu}, \mathrm{X} . ; \mathrm{Xu}, \mathrm{L}$. Structure and properties of 3-alkoxy substituted polythiophene synthesized at low temperature. Polymer 2000, 41, 9147-9154. [CrossRef]

25. Hiorns, R.C.; de Bettignies, R.; Leroy, J.; Bailly, S.; Firon, M.; Sentein, C.; Khoukh, A.; Preud'homme, H.; Dagron-Lartigau, C. High molecular weights, polydispersities, and annealing temperatures in the optimization of bulk-heterojunction photovoltaic cells based on poly(3-hexylthiophene) or poly(3-butylthiophene). Adv. Funct. Mater. 2006, 16, 2263-2275. [CrossRef]

26. Ma, W.; Yang, C.; Gong, X.; Lee, K.; Heeger, A.J. Thermally stable, efficient polymer solar cell with nanoscale control of the interpenetrating network morphology. Adv. Funct. Mater. 2005, 15, 1617-1622. [CrossRef]

27. Yang, X.; Loos, J.; Veenstra, S.C.; Verhees, W.J.H.; Wienk, M.M.; Kroon, J.M.; Michels, M.A.J.; Janssen, R.A.J. Nanoscale morphology of high-performance polymer solar cells. Nano. Lett. 2005, 5, 579-583. [CrossRef] [PubMed]

28. Michinobu, T.; Fujita, H. Postfunctionalization of alkyne-linked conjugated carbazole polymer by thermal addition reaction of tetracyanoethylene. Materials 2010, 3, 4773-4783. [CrossRef]

29. Zhao, Y.; Duan, L.; Liu, J.; Xu, Q.; Ni, Z. Optimisation of thermal annealing parameters for different thickness of active layers based on polymer/fullerene bulk heterojunction solar cells. Mater. Res. Innov. 2013, 17, S152-S155. [CrossRef]

(C) 2016 by the authors; licensee MDPI, Basel, Switzerland. This article is an open access article distributed under the terms and conditions of the Creative Commons Attribution (CC-BY) license (http://creativecommons.org/licenses/by/4.0/). 